\title{
Vulkansk aktivitet \\ - sidste halvår af 2007
}

\section{Af geolog Susanne Plesner, GeologiskNyt}

For første gang i vulkanopdateringens "levetid" på GeologiskNyt har der været aktivitet fra vulkaner i Mellemøsten. Denne aktivitet hænger sammen med aktiviteten i den Afrikanske Riftzone, der jo strækker sig op gennem Det Røde Hav. Afrika er ligeledes kommet med på landkortet igen efter at have været fraværende i første halvår af 2007. Til gengæld er der stilhed i Det Indiske Ocean.

Indonesien og Papua Ny Guinea er usædvanligt rigt repræsenteret her i sidste halvår af 2007. Aleuterne og Alaska har ligeledes givet lyd fra sig igen.

\section{Krakatau}

Vores gammelkendte Krakatau i Indonesien er begyndt at røre mere på sig, end den har gjort længe. D. 8. november kom den endda

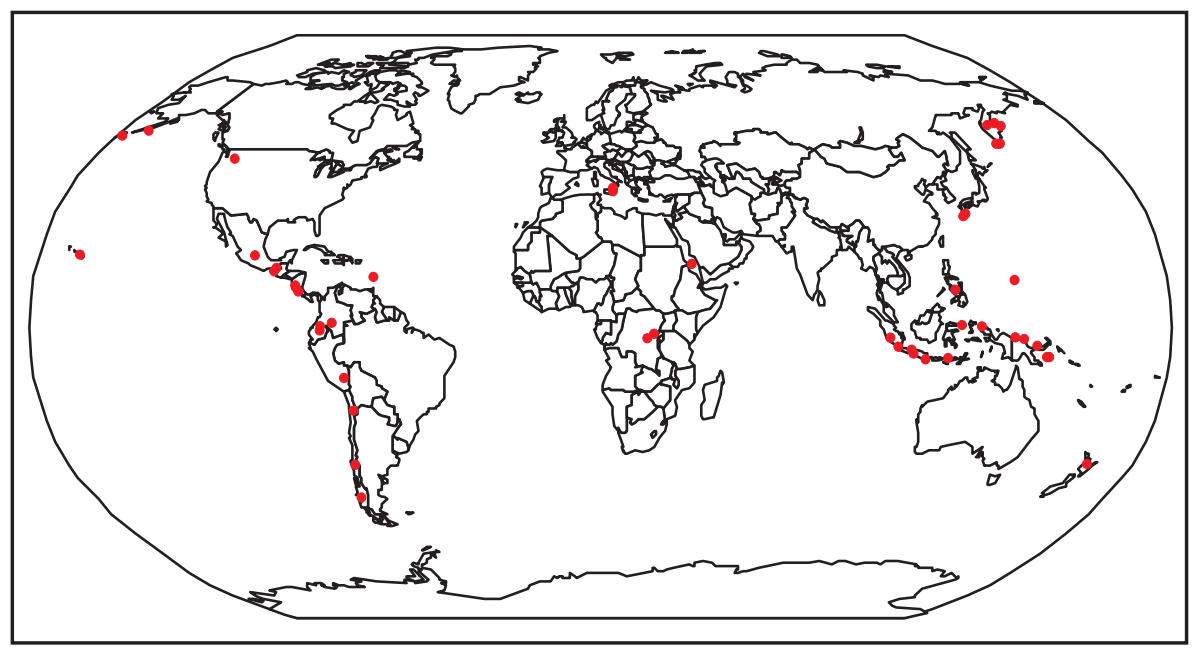

Verdenskort, den med røde fyldte cirkler viser fordelingen af den vulkanske aktivitet de seneste seks måneder. (Grafik: Forfatteren)

i fjernsynet, så langt væk som her i Danmark med rapporter om, at der var oprettet en sikkerhedszone på $3 \mathrm{~km}$ fra vulkanen.

Som mange sikkert ved, havde Krakatau et meget kraftfuldt udbrud i 1883 , hvor nogle af eksplosionerne kunne høres i Nordaustralien $2.000 \mathrm{~km}$ væk. Vulkanens udbrud i november i år med forhøjede varsler (tre på en firetrinsskala) har foranlediget nedenstående undersøgelse af, hvilke vulka-

\section{Vulkansk aktivitet de sidste 6 måneder}

Nordlige Stillehavsregion

Kilauea, Hawaii, USA

St. Helens, Washington, USA

Cleveland, Aleuterne, USA

Pavlof, Alaska, USA

Anathan, Marianer Øerne, USA

Suwanose-Jima, Ryukyu Øerne, Japan

Sakura-Jima, Kyushu, Japan

Bulusan, Filippinerne

Karangetang, Indonesien

Gamalama, Indonesien

Soputan, Sulawesi, Indonesien

Gamkonora, Indonesien

Sydlige Stillehavsregion

Semeru, Java, Indonesien

Merapi, Java, Indonesien

Raung, Java, Indonesien

Talang, Sumatra, Indonesien

Batu Tara, Indonesien

Kerinci, Sumatra, Indonesien

Soputan, Sulawesi, Indonesien

Salak, Java, Indonesien
Papandayan, Java, Indonesien

Krakatau, Indonesien

Bagana, Papua Ny Guinea

Langila, Papua Ny Guinea

Rabaul, Papua Ny Guinea

Manam, Papua Ny Guinea

Pago, New Britain, Papua Ny Guinea

Ruapehu, New Zealand

Mellemamerika, Mexico og Vestindien

Concepción, Nicaragua

Arenal, Costa Rica

Turrialba, Costa Rica

Colima, Mexico

Popocatépetl, Mexico

Fuego, Guatemala

Santa María, Guatemala

Pacaya, Guatamala

Soufriere Hills, Montserrat

Sydamerika

Tungurahau, Ecuador

Sangay, Ecuador
Reventador, Ecuador

Galeras, Colombia

Lascar, Chile

Llaima, Chile

Villarrica, Chile

Ubinas, Peru

\section{Rusland}

Karymsky, Kamchatka

Shiveluch, Kamchatka

Kliuchevskoi, Kamchatka

Bezymianny, Kamchatka

Chikurachki, Kurillerne

Afrika \& Mellemøsten

Nyiragongo, Demokratiske Republik

Congo

Ol Doinyo Lengai, Tanzania

Jebel at Tair, Yemen

Europa

Etna, Italien

Stomboli, Italien 


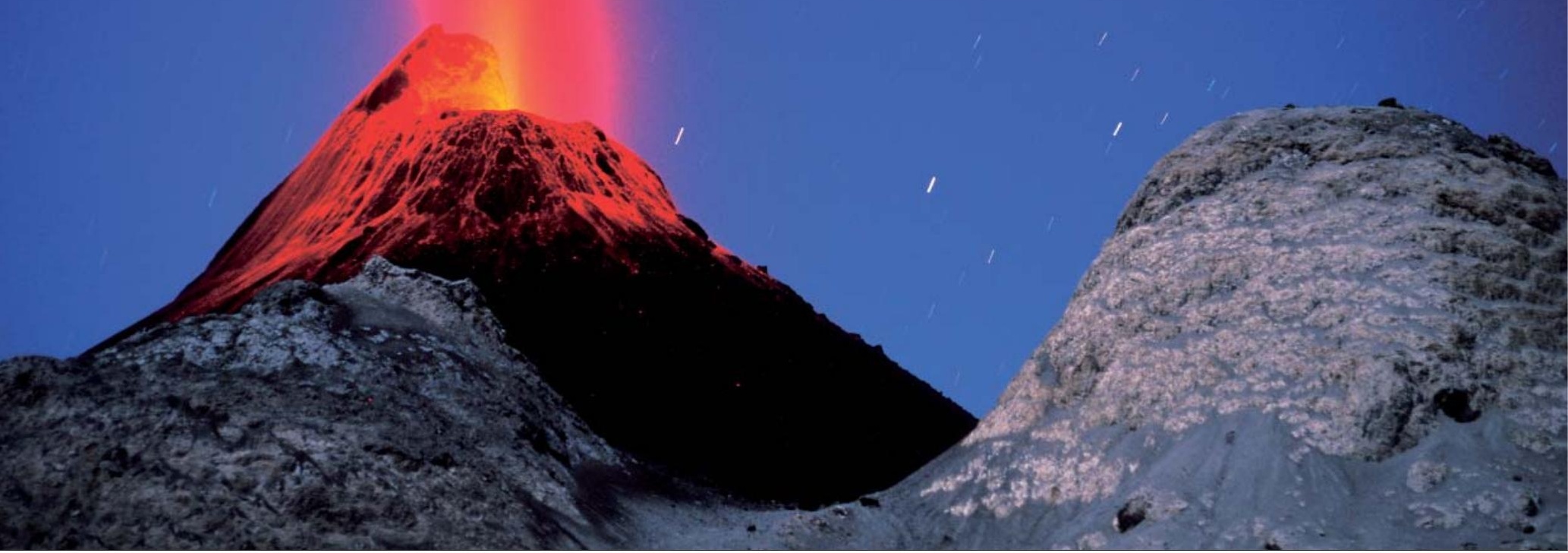

Stratovulkanen Lengai i Tanzania i udbrud. (Foto: Tom Pfeiffer, 2007)

ner der gennem tiden (historisk tid) har haft store udbrud med relativt store mennesketab og/eller klimatiske konsekvenser, der stadig udgør en potentiel fare.

\section{Udgør de stadig en signifikant trussel?}

Nedenfor er kort beskrevet fire vulkaner, der i historisk tid har haft voldsomme udbrud. Der er samtidig givet et bud på, hvor stor faren fra dem i øjeblikket er.

\section{Tambora}

Udbruddet fra Tambora i Indonesien i 1815 anses for at være blandt de største "nyere" vulkanudbrud. Det var direkte og indirekte skyld i op mod 117.000 menneskers død. Året efter, 1816, betegnes i Europa som året uden sommer, og udbrudsprodukterne var skyld i en sænkning af de globale temperaturer på op til 3 grader. I dag fremstår Tambora skovklædt og fredelig og er ikke længere registreret under potentielt aktive vulkaner. Men at dømme ud fra placeringen i Jordens mest vulkanrige stat - Indonesien - tæt på pladegrænser er det ikke sikkert, at et udbrud engang i fremtiden kan udelukkes.

\section{Kuwae}

Kuwae i Vanuatu-øgruppen er ligeledes på listen over vulkaner med omfattende udbrud. Det største i historisk tid forekom i 1452, hvor mellem 32 og $39 \mathrm{~km}^{3}$ bjergartsmateriale blev ødelagt, og en hel ø blev destrueret. Siden 1452 har vulkanen oplevet adskillige mindre udbrud, hvor mindre øer er blevet dannet for at blive eroderet væk igen. Det seneste udbrud blev registreret $i$ 1974. Aktiviteten fra den foregår i øjeblikket i form af fumarolisk aktivitet. Udbruddet i 1452 havde vejr- og klimamæssige konsekvenser, men der er ikke rapporter om tab af menneskeliv direkte i forbindelse med udbruddet.

\section{Katmai Vulkankompleks}

I 1912 oplevede Alaska et stort vulkanudbrud, som man dengang troede kom fra Katmai. Det viste sig dog, at udbruddet i stedet kom fra vulkanen Novarupta i Katmai vulkankomplekset. Ca. $35 \mathrm{~km}^{3}$ tefra blev produceret under udbruddet. $11-15 \mathrm{~km}^{3}$ af dette var en rhyolit-tuff, der nåede ca. 20 km ud fra vulkanen og dækkede et areal på $120 \mathrm{~km}^{2}$.

Calderabunden er i øjeblikket dækket af en $240 \mathrm{~m}$ dyb sø, og mindre gletschere er blevet dannet inde $\mathrm{i}$ calderaen ved siden af søen. Farvekoden, der indikerer fare for udbrud, er i øjeblikket grøn (set på en firetrinsskala bestående af farverne: grøn, gul, orange, rød. Grøn = ingen udbrud eller hvilende tilstand; rød = fare for eksplosivt udbrud inden for 24 timer; gul + orange: forskellige grader af det imellem).

\section{Pinatubo}

Inden Pinatubos (Filippinerne) udbrud i 1991 havde den været "sovende" $i$ årtier. 1991-udbruddet tegner sig for det næststørste vulkanudbrud på Jorden i det tyvende århundrede. Omkring 800 mennesker omkom, og mere end 100.000 blev hjemløse. Ca. $10 \mathrm{~km}^{3}$ materiale og millioner af tons svovldioxid blev kastet ud i atmosfæren og var skyld i en temperatursænkning for hele kloden i de efterfølgende år. Også solnedgangene var særligt røde i de efterfølgende år pga. et forhøjet indhold af askepartikler i atmosfæren.

I $2001 \mathrm{blev}$ der rapporteret om et farefuldt højt vandspejl i kratersøen. 9.000 af de ca. 46.000 indbyggere i en by $40 \mathrm{~km}$ fra vulkanen blev evakueret, og man drænede derefter ca. $25 \%$ af vandet i krateret, hvorefter folk fik lov til at vende tilbage til deres hjem.

I 2004 ændrede søen farve fra klar blågrøn til grumset brun. Denne forandring skyldtes en kombination af flere ting, men ikke fornyet vulkansk aktivitet som først frygtet. Vulkanen er i øjeblikket inaktiv med et lavt seismisk niveau, men der er ingen grund til at tro, at en gentagelse af 1991 (eller noget der ikke er helt så voldsomt) er udelukket.

Relevante links:

http://www.volcano.si.edu/reports/usgs/index.cfm?content $=$ archive http://volcano.und.nodak.edu/ http://www.volcanolive.com/large.html 